Лычагин А.И., Кузьмина Ю.А.

\title{
СОВРЕМЕННЫЕ КОНСТИТУЦИОННЫЕ ГАРАНТИИ ЗАЩИТЫ ПРАВ ЛИЧНОСТИ В РОССИЙСКОЙ ФЕДЕРАЦИИ И МЕЖДУНАРОДНЫЕ НОРМЫ В ОБЛАСТИ ЗАЩИТЫ ПРАВ ЧЕЛОВЕКА
}

\begin{abstract}
Аннотация: Статья представляет собой сравнительный анализ ключевых норм международного права в области защиты прав человека и российского конституционного законодательства. Автор оценивает уровень развития системы гарантий защиты прав личности в Российской Федерации.

Review: The article contains a comparative analysis of the main standards of international human rights laws and Russian constitutional legislation. The author evaluates the level of development of the human rights system in the Russian Federation.
\end{abstract}

Ключевые слова: Политология, Конституция, права человека, Российская Федерачия, международное право, Европейская конвенция о защите прав человека, смертная казнь, гражданское общество, федеральные законы, принцииь

Keywords: political studies, Constitution, human rights, Russian Federation, international law, European Convention on Human Rights, death penalty, civil society, federal laws, principles.

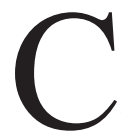
о второй половины 80-х годов в российском обществе с учетом международного опыта начал утверждаться новый подход к проблеме прав человека, стали преодолеваться серьезные нарушения в этой области. Было очевидно, что российское законодательство о правах человека значительно отставало от развитых в этом отношении европейских государств, и потому назрела потребность приведения его в соответствие с положениями Всеобщей декларации прав человека 1948 г., Европейской конвенции о защите прав человека 1950 г., Международных пактов о правах человека 1966 г., Итоговых документов Мадридской и Венской встреч, других конвенций и соглашений.

Решающее значение имело признание нашим государством в соответствии с Итоговым документом Венской встречи 1989 г., примата международного права по отношению к внутренним законам, в том числе и в сфере соблюдения прав человека. В ноябре 1991 г. в России была принята Декларация прав и свобод человека и гражданина, в первой же статье которой подчеркивалось: «Общепризнанные международные нормы, относящиеся к правам человека, имеют преимущество перед законами РСФСР и непосредственно порождают права и обязанности граждан РСФСР» ${ }^{1}$.

${ }^{1}$ Декларация прав и свобод человека и гражданина. Принята Верховным Советом РСФСР 22 ноября 1991г. // Ведомости
В связи с подачей заявки на вступление в Совет Европы (7 мая 1992 года) в стране была проведена интенсивная работа по приведению российского законодательства в соответствие с европейскими требованиями и международными соглашениями. С этого времени Россия стала принимать непосредственное участие в различных направлениях деятельности Совета Европы, в выполнении межправительственных программ «сотрудничества и содействия», а с апреля 1993 г. совместно с Советом Европы начал осуществляться Проект гармонизации российского законодательства с европейскими нормами в области прав человека. Группой известных отечественных юристов - международников, доктором юридических наук, профессором Ю.М. Колосовым, доктором юридических наук, профессором Л.М. Энтиным, доктором юридических наук, профессором И.Л. Петрухиным и доктором юридических наук, профессором, судьей Европейского суда по правам человека от Российской Федерации А.И. Ковлером и другими, была проведена значительная работа по сопоставлению национального законодательства и практики с принципами и стандартами Совета Европы на базе Института Европейского права МГИМО(у) и Института государства и права РАН

Съезда народных депутатов РСФСР и Верховного Совета РСФСР. - 1991. - №52. - Ст.1865. 
в рамках Программы сотрудничества Совета Европы, Европейской Комиссии и Российской Федерации.

По итогам экспертного исследования Главным государственно-правовым управлением Президента Российской Федерации был разработан План подготовки в 1998 году первоочередных законопроектов для приведения законодательства Российской Федерации в соответствие с Конвенцией о защите прав человека и основных свобод, который был утвержден Президентом Российской Федерации 29 марта 1998 года № ПР-437.

В соответствии с Планом был подготовлен проект Федерального закона «О внесении изменений и дополнений в некоторые законодательные акты Российской Федерации в связи с ратификацией Конвенции о защите прав человека и основных свобод», который был подписан Президентом РФ 20 марта 2001 года № 26-Ф3².

Переломным моментом в процессе утверждения в российской правовой системе международных и европейских стандартов в области прав человека стало принятие Конституции Российской Федерации 1993 г., вступившей в силу 25 декабря 1993 года. Её положения опираются на основные принципы и нормы европейских и международных конвенций и пактов по правам человека ${ }^{3}$.

Правам и свободам человека и гражданина, в целом, посвящена глава 2 Конституции РФ (ст.17 - 64). Однако, основные принципы закреплены и в главе 1 «Основы конституционного строя». Так, согласно статье 1, Россия признается «демократическим правовым государством», что предполагает обеспечение прав и свобод человека, характерных для демократического общества. Статья 2 провозглашает права и свободы высшей ценностью государства. Согласно статье 7 РФ является «социальным государством». Статья 8 закрепляет принцип свободы экономической деятельности. Особое следует подчеркнуть, что в соответствии со статьёй 15 Конституции международные нормы по правам че-

\footnotetext{
${ }^{2}$ Ф3 «О внесении изменений и дополнений в некоторые законодательные акты Российской Федерации в связи с ратификацией Конвенции о защите прав человека и основных свобод» от 20 марта 2001 года № 26-Ф3 // Информационноправовое издание Legis.ru [сайт]. URL: http://www.legis.ru/ $\mathrm{misc/doc/2890/(дата} \mathrm{обращения:} \mathrm{4.12.2009).}$

${ }^{3}$ Горшкова С.A. О гарантиях прав российских граждан Европейской конвенцией // Международное публичное и частное право. - 2003. - №1(10). - С.21.
}

ловека имеют приоритетное значение по сравнению с конституционными ${ }^{4}$.

В Постановлении Пленума Верховного Суда РФ «О некоторых вопросах применения судами Конституции Российской Федерации при осуществлении правосудия» еще раз подчеркнуто, что суд при рассмотрении дела не вправе применять нормы закона, регулирующего возникшие правоотношения, если вступившим в силу для Российской Федерации международным договором установлены иные правила, чем предусмотренные законом. В этих случаях применяются правила международного договоpa Российской Федерации. Положения официально опубликованных международных договоров Российской Федерации, не требующие издания внутригосударственных актов для применения, действуют в Российской Федерации непосредственно ${ }^{5}$.

Под действие части 4 статьи 15 Конституции полностью подпадают Конвенция о защите прав человека основных свобод и протоколы к ней. Они относятся к международным договорам, под которыми согласно Федеральному закону «О международных договорах Российской Федерации» понимается любое «международное соглашение, заключенное Российской Федерацией с иностранным государством (или государствами) либо с международной организацией в письменном виде и регулируемое международным правом» ${ }^{6}$.

В статье 17 российской Конституции прямо указывается, что «в Российской Федерации признаются и гарантируются права и свободы человека и гражданина согласно общепризнанным принципам и нормам международного права» ${ }^{7}$ В этой статье также закреплены положения Всеобщей декларации прав человека о естественной природе и неотчуждаемости прав и свобод человека. В то же время их осуществление не должно нарушать права и свободы других лиц.

${ }^{4}$ Конституция Российской Федерации 1993 г. // Конституция Российской Федерации [сайт]. URL: http://www.constitution. $\mathrm{ru} /$ (дата обращения: 4.12.2009).

${ }^{5}$ Постановление Пленума Верховного Суда РФ от 31 октября 1995 г. N 8 «О некоторых вопросах применения судами Конституции Российской Федерации при осуществлении правосудия» // Конституция Российской Федерации [сайт]. URL: http://www.constitution.ru/decisions/10003328/10003328.htm (дата обращения: 4.12.2009).

${ }^{6}$ Туманов В.А. Европейский Суд по правам человека: очерк организации и деятельности. М., 2001. С.47-53.

${ }^{7}$ Конституция Российской Федерации 1993 г. 


\section{Политика и общество 7 (103) • 2013}

Кроме того, в соответствии со статьёй 18 Конституции Российской Федерации «права и свободы человека и гражданина являются непосредственно действующими, то есть для их осуществления не требуется принятия каких-либо специальных законов или тем более подзаконных актов» ${ }^{8}$.

При проведении сравнительного анализа Конституции РФ и Европейской конвенции о защите прав человека и основных свобод 1950 г., ключевого международного документа в области защиты прав человека, можно сделать вывод, что в Конституции нашёл отражение полный каталог прав и свобод, гарантируемых в современных демократических государствах. Для фактического подтверждения приведенного утверждения приведем следующую таблицу:

\begin{tabular}{|c|c|c|}
\hline $\begin{array}{l}\text { Принцип, закрепленный } \\
\text { в Конституции Российской } \\
\text { Федерации } 1993 \text { г. }\end{array}$ & $\begin{array}{l}\text { Статья Конституции } \\
\text { Российской Федерации } \\
1993 \text { г., содержащая } \\
\text { указанный принцип }\end{array}$ & $\begin{array}{l}\text { Статья одной из Конвенций Совета } \\
\text { Европы в области защиты прав } \\
\text { человека, содержащая указанный } \\
\text { принцип }\end{array}$ \\
\hline $\begin{array}{l}\text { Принцип равенства прав } \\
\text { и свобод и недопущение } \\
\text { дискриминации }\end{array}$ & Ст.19 & $\begin{array}{l}\text { Ст.1 и Ст.14 Европейской конвенции о } \\
\text { защите прав человека, Ст.1 Протокола } \\
12 \text { к Европейской конвенции о защите } \\
\text { прав человека }\end{array}$ \\
\hline Право на жизнь & Ст.20 & $\begin{array}{l}\text { Ст.2 Европейской конвенции о защите } \\
\text { прав человека }\end{array}$ \\
\hline $\begin{array}{l}\text { Право на личную } \\
\text { неприкосновенность }\end{array}$ & Ст. 22 & $\begin{array}{l}\text { Ст. } 5 \text { Европейской конвенции о защите } \\
\text { прав человека }\end{array}$ \\
\hline $\begin{array}{l}\text { Право на неприкосновенность } \\
\text { личной жизни }\end{array}$ & Ст. $23-25$ & $\begin{array}{l}\text { Ст.8 Европейской конвенции о защите } \\
\text { прав человека }\end{array}$ \\
\hline $\begin{array}{l}\text { Свобода совести, вероисповедания, } \\
\text { мысли, слова, информации }\end{array}$ & Ст.28, 29 & $\begin{array}{l}\text { Ст.9 Европейской конвенции о защите } \\
\text { прав человека }\end{array}$ \\
\hline $\begin{array}{l}\text { Право на свободу мирных } \\
\text { собраний }\end{array}$ & Ст. 30,31 & $\begin{array}{l}\text { Ст. } 11 \text { Европейской конвенции о защите } \\
\text { прав человека }\end{array}$ \\
\hline $\begin{array}{l}\text { Право избирать и быть } \\
\text { избранными }\end{array}$ & Ст. 32 & $\begin{array}{l}\text { Ст.3 Протокола } 1 \text { к Европейской } \\
\text { конвенции о защите прав человека }\end{array}$ \\
\hline $\begin{array}{l}\text { Право участвовать в отправлении } \\
\text { правосудия }\end{array}$ & Ст. 32 & - \\
\hline $\begin{array}{l}\text { Право на равный доступ к } \\
\text { государственной службе }\end{array}$ & Ст. 32 & - \\
\hline $\begin{array}{l}\text { Право обращаться в } \\
\text { государственные органы и органы } \\
\text { местного самоуправления }\end{array}$ & Ст. 33 & - \\
\hline $\begin{array}{l}\text { Свобода предпринимательской } \\
\text { деятельности }\end{array}$ & Ст. 34 & - \\
\hline Право частной собственности & Ст. 35-36 & $\begin{array}{l}\text { Ст.1 Протокола } 1 \text { к Европейской } \\
\text { конвенции о защите прав человека }\end{array}$ \\
\hline Свобода Труда & Ст. 37 & Ст.1 Европейской социальной хартии \\
\hline
\end{tabular}

${ }^{8}$ Конституция Российской Федерации. Комментарий / Под ред. Б.Н. Топорнина. М., 1994 г. С.78 
Основные права и свободы

\begin{tabular}{|c|c|c|}
\hline $\begin{array}{l}\text { Запрещение принудительного } \\
\text { труда }\end{array}$ & Ст. 37 & $\begin{array}{l}\text { Ст. } 4 \text { Европейской конвенции о защите } \\
\text { прав человека }\end{array}$ \\
\hline Право на социальное обеспечение & Ст. 39 & Ст.12 Европейской социальной хартии \\
\hline Право на жилище & Ст. 40 & - \\
\hline $\begin{array}{l}\text { Право на охрану здоровья и } \\
\text { медицинскую помощь }\end{array}$ & Ст. 41 & Ст.13 Европейской социальной хартии \\
\hline $\begin{array}{l}\text { Право на благоприятную } \\
\text { окружающую среду }\end{array}$ & Ст. 42 & - \\
\hline Право на образование & Ст. 43 & $\begin{array}{l}\text { Ст.2 Протокола } 1 \text { к Европейской } \\
\text { конвенции о защите прав человека }\end{array}$ \\
\hline $\begin{array}{l}\text { Право на справедливое судебное } \\
\text { разбирательство }\end{array}$ & Ст. $47-54$ & $\begin{array}{l}\text { Ст. } 6,7 \text { Европейской конвенции о защите } \\
\text { прав человека }\end{array}$ \\
\hline $\begin{array}{l}\text { Право на эффективное средство } \\
\text { правовой защиты }\end{array}$ & Ст. 45,46 & $\begin{array}{l}\text { Ст. } 13 \text { Европейской конвенции о защите } \\
\text { прав человека }\end{array}$ \\
\hline Запрещение высылки граждан & Ст. 61 & $\begin{array}{l}\text { Ст.3 Протокола } 4 \text { к Европейской } \\
\text { конвенции о защите прав человека }\end{array}$ \\
\hline Свобода передвижения & Ст. 27 & $\begin{array}{l}\text { Ст.2 Протокола } 4 \text { к Европейской } \\
\text { конвенции о защите прав человека }\end{array}$ \\
\hline $\begin{array}{l}\text { Право определять и указывать } \\
\text { свою национальную } \\
\text { принадлежность }\end{array}$ & Ст. 26 & $\begin{array}{l}\text { Ст.3 Рамочной конвенции о защите прав } \\
\text { национальных меньшинств }\end{array}$ \\
\hline $\begin{array}{l}\text { Право на пользование родным } \\
\text { языком }\end{array}$ & Ст. 26 & $\begin{array}{l}\text { Ст.10 Рамочной конвенции о защите } \\
\text { прав национальных меньшинств }\end{array}$ \\
\hline Равенство между супругами & Ст. 38 & $\begin{array}{l}\text { Ст.5 Протокола } 7 \text { к Европейской } \\
\text { конвенции о защите прав человека }\end{array}$ \\
\hline $\begin{array}{l}\text { Право на пересмотр приговора } \\
\text { вышестоящим судом }\end{array}$ & Ст. 50 & $\begin{array}{l}\text { Ст.2 Протокола } 7 \text { к Европейской } \\
\text { конвенции о защите прав человека }\end{array}$ \\
\hline $\begin{array}{l}\text { Никто не может быть повторно } \\
\text { осужден за одно и то же } \\
\text { преступление }\end{array}$ & Ст. 50 & $\begin{array}{l}\text { Ст.4 Протокола } 7 \text { к Европейской } \\
\text { конвенции о защите прав человека }\end{array}$ \\
\hline $\begin{array}{l}\text { Право на компенсацию } \\
\text { причиненного ущерба }\end{array}$ & Ст. 52 & $\begin{array}{l}\text { Ст.3 Протокола } 7 \text { к Европейской } \\
\text { конвенции о защите прав человека }\end{array}$ \\
\hline
\end{tabular}

Пункт 2 статьи 20 Конституции регулирует вопрос о применении смертной казни. До последнего времени России не удавалось решить законодательно вопрос о правовой отмене смертной казни и ратифицировать Протокол №6 к Конвенции о защите прав человека и основных свобод.

Хотя в Конституции страны, в Уголовном кодексе и Уголовно-процессуальном кодексе содержатся нормы о применении смертной казни, однако факти- чески Указом Президента России с 4 августа 1996 г. осуществляется мораторий на применение смертной казни. Конституционный Суд Российской Федерации в своем постановлении от 2 февраля 1999 г., учитывая, что во многих регионах страны нарушается право подсудимых на суд присяжных, ввел мораторий на вынесение смертных приговоров, а Президент РФ Указом от 3 июня 1999 г. отменил исполнение всех уже вынесенных смертных приговоров в стране. 


\section{Политика и общество $7(103) \cdot 2013$}

Вместе с тем Россия не выполнила обязательство перед Советом Европы в этой области, не приняв закон об отмене смертной казни 9 .

Правовая корректность требует одновременно с предстоящей ратификацией Протокола № 6 внесения соответствующих изменений в УК, т.е. изъять смертную казнь как вид уголовного наказания ${ }^{10}$.

Исключительную важность для решения вопросов регулирования и защиты прав и свобод человека имеет статья 55 Конституции, согласно которой в РФ не должны издаваться законы, отменяющие или умаляющие права и свободы человека и гражданина (ч.2 ст.55); права и свободы человека и гражданина могут быть ограничены федеральным законом только в той мере, в какой это необходимо в целях защиты основ конституционного строя, нравственности, здоровья, прав и законных интересов других лиц, обеспечения обороны страны и безопасности государства (ч.3 ст.55).

Значение этой конституционной нормы состоит в том, что она:

1) содержит юридические гарантии защиты прав человека от произвольного нарушения их самим федеральным законодателем и от нарушений со стороны органов должностных лиц представительной и исполнительной властей;

2) устанавливает для федерального законодателя критерии принимаемых законов и пределы, за которые он, ограничивая некоторые права и свободы человека и гражданина, не может переходить;

3) создает для суда правовую базу, на основании которой он может разрешать коллизии между нормативными актами и решать вопросы, связанные с их соответствием Конституции Р $\Phi^{11}$.

В статьях 57-59 Конституции речь идет об обязанностях гражданина РФ. К ним относятся: обязанность платить налоги и сборы; обязанность сохранять природу и окружающую среду; обязан-

\footnotetext{
9 Горшкова С.А. О выполнении Россией европейских конвенционных обязательств по правам человека // Право и политика. - 2002. - №3. - С. 15 - 23.

${ }^{10}$ Воинов И. Разрешение коллизий норм европейского и российского права // Российская Юстиция. - 2001. - №6. - С.34 -41 .

${ }^{11}$ Калашников С.В. Система конституционных гарантий обеспечения прав и свобод личности в условиях формирования в России гражданского общества // Государство и Право. 2002. - №10. C.34-42.
}

ность защищать Отечество. Согласно статье 60 Конституции, гражданин обладает правами и обязанностями с 18 лет ${ }^{12}$.

Заключительная статья главы 2 Конституции, статья 64 характеризует вышеперечисленные положения как «основу статуса личности в РФ».

Согласно пункту «в» статьи 71 регулирование прав и свобод человека и гражданина находится в ведении Российской Федерации. Это значит, что субъекты Федерации осуществлять законодательное регулирование конституционных прав и свобод человека не могут; в их совместном с Федерацией ведении находится лишь защита прав и свобод человека (п.«б» ст.72 Конституции) ${ }^{13}$.

В ведении Российской Федерации находится также и регулирование других отношений, которые тесно связаны с конституционными правами человека и поэтому должны быть единообразно урегулированы на всей территории РФ: уголовное, уголовно-процессуальное законодательство; гражданское, гражданско-процессуальное и арбитражно-процессуальное законодательство; интеллектуальная собственность (п.«о» ст.71) ${ }^{14}$.

Нельзя не обратить внимание на то, что некоторые права и свободы человека и гражданина закреплены в Конституции декларативно, - например, право каждого на жилище (ч.1 ст.40), право каждого на благоприятную окружающую среду (ст.42). Для суда, который в случае нарушения прав человека должен обеспечить их защиту, но который, естественно, не в состоянии ни предоставить гражданам жилище, ни гарантировать благоприятную окружающую среду, главное в этих нормах, очевидно, в том, что согласно части 1 статьи 40 никто не может быть произвольно лишен жилища, а статья 42 - что каждый имеет право на возмещение ущерба, причиненного его здоровью или имуществу экологическим правонарушением. В этих и подобных случаях реализации других прав суд имеет возможность и обязан обеспечить их защиту ${ }^{15}$.

В целях обеспечения прав и свобод человека и гражданина Конституция предусматривает, что огра-

\footnotetext{
${ }^{12}$ Конституция Российской Федерации 1993 г.

13 Там же.

${ }^{14}$ Батырь B.A. Имплементация норм международного гуманитарного права в законодательстве Российской Федерации. М., 2000г. С.117.

15 Тиунов О.И. Международное гуманитарное право: Учебник для вузов. М., 1999 г. С. 125.
} 
ничения некоторых, наиболее важных из них, допускаемые на оснований федерального закона, каждый раз осуществляются с соблюдением дополнительной гарантии - с санкции (по решению) суда. Речь идёт о праве на жизнь (ч.2 ст.20 Конституции), на свободу и личную неприкосновенность (ч.2 ст.22), на неприкосновенность частной жизни: на тайну переписки, телефонных переговоров, почтовых, телеграфных и иных сообщений (ст.23 Конституции), на неприкосновенность жилища (ст.25 Конституции), частной собственности (ст. 35), праве каждого обвиняемого в совершении преступления считаться невиновным, пока его виновность не будет доказана в предусмотренном Федеральным законом порядке и установлена вступившим в законную силу приговором суда (ст.49) ${ }^{16}$.

Конституция РФ 1993 г. не только закрепляет права и свободы человека и гражданина, но и предусматривает серьезные гарантии стабильности ее положений: сам законодатель - Федеральное Собрание - согласно части 1 статьи 135 не может их пересмотреть ${ }^{17}$.

Помимо Конституции в России существует целый ряд законов, затрагивающих вопросы правового положения личности в государстве. К ним можно отнести ФКЗ «О военном положении» от 30.01.2002 г., ФКЗ «О чрезвычайном положении» от 30.05.2001 г., ФКЗ «Об Уполномоченном по правам человека в Российской Федерации» от 26.01.1997 г., Ф3 «О собраниях, митингах, демонстрациях, шествиях и пикетированиях» от 19.06.2004 г., Ф3 «О правовом положении иностранных граждан в Российской Федерации» от 25.07.2002 г., Ф3 «Об основных гарантиях избирательных прав и права на участие в референдуме граждан Российской Федерации» от 12.06.2002 г., Ф3 «О гражданстве Российской Федерации» от 31.05.2002, Ф3 «О политических партиях» от 11.07.2001 г., Ф3 «О государственной политике Российской Федерации в отношении соотечественников за рубежом» от 24.05.1999 г., Ф3 «О гарантиях прав коренных малочисленных народов Российской Федерации» от 30.04.1999 г., Ф3 «Об основных гарантиях прав ребёнка» от 24.07.1998 г., Ф3 «О воинской обязанности и военной службе» от 28.03.1998 г., Ф3 «О свободе совести и о религиозных объединениях» от 26.09.1997 г., Ф3 «Об обеспечении конституционных прав граждан Российской Федерации избирать и быть избранными в

\footnotetext{
${ }^{16}$ Калашников С.В. Указ. соч. С.34-42.

${ }^{17}$ Тиунов О.И. Указ. соч. С.126.
}

органы местного самоуправления» от 26.11.1996 г., Ф3 «О порядке выезда из Российской Федерации и въезда в Российскую Федерацию» от 15.08.1996 г., Ф3 «О национально-культурной автономии» от 17.06.1996 г., Ф3 «О беженцах» от 19.02.1993 г., Закон РФ «Об образовании» от 10.07.1992 г., Ф3 «О содержании под стражей подозреваемых и обвиняемых в совершении преступлений» от 15.07.1995 г., Закон РФ «О праве граждан Российской Федерации на свободу передвижения, выбор места пребывания и жительства в пределах Российской Федерации» от 25.06.1993 г., Закон РФ «Об обжаловании в суд действий и решений, нарушающих права и свободы граждан» от 27.04.1993 г., Закон РФ «О языках народов Российской Федерации» от 25.10.1991 г.

Кроме того, были приняты федеральные законы и указы Президента России по укреплению вертикали государственной власти и созданию единого правового пространства в стране, обязывающие субъекты Российской Федерации привести свои правовые акты, в том числе и в области защиты прав человека, в соответствие с федеральным законодательством и общепризнанными международными и европейскими нормами ${ }^{18}$.

Согласно статье 56 Конституции РФ 1993 г. отдельные ограничения прав и свобод могут устанавливаться в условиях чрезвычайного положения для обеспечения безопасности граждан и защиты конституционного строя на всей территории РФ или в ее отдельных местностях, где вводится такое положение, другими органами государственной власти, но это делается в соответствии с Федеральным конституционным законом и на определенный срок ${ }^{19}$.

На сегодняшний день в российском конституционном законодательстве закреплены все права и свободы, провозглашенные в документах Совета Европы. Россия соответствует с правовой точки зрения европейскому уровню в деле обеспечения прав человека. Единственным нереализованным обязательством государства перед указанной организацией является ратификации Протокола №6 к Европейской конвенции о защите прав человека и основных свобод, требующего отмены смертной казни.

\footnotetext{
${ }^{18}$ Горшкова С.A. Европейские нормы по правам человека и усилия России по их соблюдению // Журнал Российского Права. - 2001. - №6. С.17-27.

${ }^{19}$ Конституция Российской Федерации. Комментарий. С. $287-$ 288.
} 


\section{Политика и общество $7(103) \cdot 2013$}

\section{Библиография:}

1. Конституция Российской Федерации 1993 г. [Электронный ресурс]. - Режим доступа: http:// www.constitution.ru/. Дата обращения: 9.12.2009.

2. Федеральный закон «О внесении изменений и дополнений в некоторые законодательные акты РФ в связи с ратификацией Конвенции о защите прав человека и основных свобод» // Российская газета. $-2001-.-23$ марта.

3. Декларация прав и свобод человека и гражданина. Принята Верховным Советом РСФСР 22 ноября 1991г.: Ведомости Съезда народных депутатов РСФСР и Верховного Совета РСФСР, 1991, №52, Ст.1865. - М. : Ось-89, 1993. - 45 с.

4. Постановление Пленума Верховного Суда РФ «О некоторых вопросах применения судами Конституции Российской Федерации при осуществлении правосудия» от 31 октября 1995 г. N 8 [Электронный ресурс]. - Режим доступа: http://www. constitution.garant.ru/DOC_10003328.htm. Дата обращения: 9.12.2009.

5. Батырь, В.А. Имплементация норм международного гуманитарного права в законодательстве РФ. - М.: Гендальф, 2000. - 67 с.

6. Воинов И. Разрешение коллизий норм европейского и российского права // Российская Юстиция. - 2001. - №6. - С.34 - 41.

7. Горшкова С.А. Европейские нормы по правам человека и усилия России по их соблюдению // Журнал Российского Права. - 2001. - №6. С.17-27.

8. Горшкова С.А. О выполнении Россией европейских конвенционных обязательств по правам человека // Право и политика. - 2002. - №3. - С. 15 - 23.

9. Горшкова С.А. О гарантиях прав российских граждан Европейской конвенцией // Международное публичное и частное право. - 2003. №1(10). - C.21.

10. Калашников С.В. Система конституционных гарантий обеспечения прав и свобод личности в условиях формирования в России гражданского общества // Государство и Право. - 2002. - №10. C.34-42.
11. Конституция Российской Федерации. Комментарий / Под ред. Б.Н. Топорнина. М., 1994 г.

12. Общая теория прав человека / Отв. ред. Е.А. Лукашева. - М.: Норма, 1996. - 520 с.

13. Тиунов, О.И. Международное гуманитарное право: учебник для вузов по юридич спец. и напр. / О.И. Тиунов. - М.: НОРМА - ИНФРА-М, 1999. $-315 \mathrm{c}$.

14. Туманов, В.А Европейский суд по правам человека: очерк организации и деятельности / В.А. Туманов. - М.: НОРМА, 2001. - 295 с.

\section{References (transliteration):}

1. Batyr', V.A. Implementaciya norm mezhdunarodnogo gumanitarnogo prava $\mathrm{v}$ zakonodatel'stve RF. M.: Gendal'f, 2000. -67 s.

2. Voinov I. Razreshenie kolliziy norm evropeyskogo i rossiyskogo prava // Rossiyskaya Yusticiya. - 2001. - №6. - S.34 - 41 .

3. Gorshkova S.A. Evropeyskie normy po pravam cheloveka i usiliya Rossii po ih soblyudeniyu // Zhurnal Rossiyskogo Prava. - 2001. - №6. S.17-27.

4. Gorshkova S.A. O vypolnenii Rossiey evropeyskih konvencionnyh obyazatel'stv po pravam cheloveka // Pravo i politika. - 2002. - №3. - S. 15 - 23.

5. Gorshkova S.A. O garantiyah prav rossiyskih grazhdan Evropeyskoy konvenciey // Mezhdunarodnoe publichnoe i chastnoe pravo. - 2003. - №1(10). S.21.

6. Kalashnikov S.V. Sistema konstitucionnyh garantiy obespecheniya prav i svobod lichnosti $\mathrm{v}$ usloviyah formirovaniya v Rossii grazhdanskogo obschestva // Gosudarstvo i Pravo. - 2002. - №10. S.34-42.

7. Obschaya teoriya prav cheloveka / Otv. red. E.A. Lukasheva. - M.: Norma, 1996. - 520 s.

8. Tiunov, O.I. Mezhdunarodnoe gumanitarnoe pravo: uchebnik dlya vuzov po yuridich spec. i napr. / O.I. Tiunov. - M.: NORMA - INFRA-M, 1999. - $315 \mathrm{~s}$.

9. Tumanov, V.A Evropeyskiy sud po pravam cheloveka: ocherk organizacii i deyatel'nosti / V.A. Tumanov. - M.: NORMA, 2001. - 295 s. 